\title{
Tolerance of the deposit-feeding Baltic amphipods Monoporeia affinis and Pontoporeia femorata to oxygen deficiency
}

\author{
Birgitta Johansson* \\ Department of Zoology, Stockholm University, S-10691 Stockholm, Sweden
}

\begin{abstract}
Tolerances of the 2 most common species of amphipods in the Baltic Sea to low oxygen concentrations were determined over a range of ambient salinities in the Baltic. For both species more than half of the tested individuals had died by the end of $24 \mathrm{~h}$ of exposure to nearly anoxic water $\left(0.2 \mathrm{mg} \mathrm{O}_{2} \mathrm{l}^{-1}\right)$. Despite its higher respiration rate and level of activity, Monoporeia affinis was significantly more tolerant than Pontoporeia femorata both to short ( 1 to $5 \mathrm{~d}$ ) and long ( $24 \mathrm{~d}$ ) periods of exposure to low oxygen levels. As long as the amphipods survived the tested salinity, there were only minor effects of salinity on their tolerance to oxygen deficiency. Among the common macrobenthic softbottom species in the study area, $M$. affinis and $P$. femorata seem to be the most sensitive to oxygen deficiency.
\end{abstract}

KEY WORDS: Oxygen deficiency Salınity Amphipods Monoporeia affinıs Pontoporeia femorata Baltic Sea

\section{INTRODUCTION}

Today, benthic oxygen deficiency occurs as a shortor long-term phenomenon in many estuarine and shatlow coastal areas. Density stratification of the water by a pycnocline, preventing oxygen exchange between surface and bottom water, is one important reason why oxygen deficiency occurs. Where present, eutrophication aggravates the phenomenon by enhancing oxygen consumption in the bottom water layer, often resulting in oxygen levels low enough to negatively affect the benthic community (Officer et al. 1984, Rosenberg et al. 1990, de Jong et al. 1994, Turner \& Rabalais 1994, review in Diaz \& Rosenberg 1995). In extreme cases, mass mortality (Steimle \& Sinderman 1978, Jørgensen 1980) and emigration from affected areas have been reported (Baden et al. 1990). But long before such dramatic events occur, oxygen deficiency reduces benthic biomass (Gaston 1985, Friligos \& Zenetos 1988), changes species composition (Llansó 1992), and depresses growth (Weber \& Kramer 1983, Nilsson \& Sköld 1996) and feeding rates (Widdows et al. 1989).

\footnotetext{
•E-mail: birgitta.johansson@zoologi.su.se
}

The present study is focused on the Baltic Sea proper, known for vast areas depleted of animals through oxygen deficiency (Andersin et al. 1978). The permanent halocline in the Baltic Sea prevents mixing of the water column, and as a result anoxia and hydrogen sulphide occur commonly in the deep water (Andersin et al. 1978). The area affected varies depending on intrusions of oxygenated water from the North Sea, which normally occur every 3 to 4 yr (Matthäus \& Franck 1992). This oxygen deficiency is partly a natural phenomenon. However, during the present century the oxygen deficiency has worsened and the areas affected have increased due to eutrophication. The input of nitrogen to the Baltic Sea has increased about 4 times and that of phosphorus 8 times in this century (Larsson et al. 1985). These nutrients have stimulated pelagic primary production. Above the halocline the macrobenthic biomass has increased (Cederwall \& Elmgren 1980) and below it the elevated sedimentation rate of organic material has increased oxygen consumption (review in Elmgren 1989). A decrease in number of species and macrofaunal biomass, or their total disappearance, has been reported as a result of oxygen deficiency (Cederwall \& Elmgren 
1990). When the oxygen concentration increases, recolonization by macrofauna may follow (Leppäkoski 1969, Andersin et al. 1978, Gosselck \& Georgi 1984, Andersin et al. 1990, Andersin \& Sandler 1991).

The objective of this study was to measure the tolerance to oxygen deficiency of the 2 most abundant macrobenthic animals in the Baltic Sea, the amphipods Monoporeia affinis (Lindström) and Pontoporeia femorata Krøyer. Both live in soft sediments, $M$. affinis mainly from $20 \mathrm{~m}$ depth and downwards and $P$. femorata below $30 \mathrm{~m}$ depth (Segerstråle 1950, Järvekülg 1973). Most individuals are found in the upper $5 \mathrm{~cm}$ of the sediment, but they burrow down to $13 \mathrm{~cm}$, with $P$. femorata on average found deeper than $M$. affinis (Hill \& Elmgren 1987). Both species are deposit-feeders and primarily ingest the upper sediment layer (Lopez \& Elmgren 1989). P. femorata has a lower respiration rate and is less active than $M$. affinis (Cederwall 1979). These amphipod species are important as prey for fish (Aneer 1975) and larger invertebrates (Abrams et al. 1990, Hill \& Elmgren 1992), and probably also as effective bioturbators which influence the biogeochemical processes in the sediment as described for Pontoporeia hoyi (Robbins 1982). It is thus important to improve our knowledge of their tolerance to the oxygen deficiency that affects large areas of the Baltic Sea bottom.

\section{METHODS}

General methods. Field collections and experiments were carried out during summer. Sediment and animals were collected with a benthic sled at 30 to $40 \mathrm{~m}$ in the Baltic Sea, close to the Asko Laboratory $(80 \mathrm{~km}$ south of Stockholm), where natural sea water was obtained. The sediment was homogenised by sieving through a $0.5 \mathrm{~mm}$ screen. The amphipods were of the $1+$ age class, hatched in early spring of the previous year. All experiments were run in a temperature-controlled room at $5^{\circ} \mathrm{C}$. The light and dark periods were regulated with a timer, and a dim green light (simulating natural conditions) was on between 07:00 and 19:00 h in the first 2 experiments and between 05:00 and 21:00 h in the third tolerance experiment. Unless otherwise noted, the tank water had the same salinity as the water in which the amphipods had been collected ( $6.5 \%$ ).

The experiments were run in rectangular tanks, and the water was recirculated with a pump $\left(440 \mathrm{I} \mathrm{h}^{-1}\right)$. The oxygen electrode was placed at the inlet end, and nitrogen gas was supplied at the outlet end. which was screened off from the animal containers. The oxygen concentration was monitored with an oxygen meter (AOWL2/KOB/421, Processtyrning AB, Sweden), and the readings were stored on a data logger (Analog Connection Jr and QuickLog PC, Strawberry Tree
Inc., USA). The accuracies of the oxygen meters were regularly checked, and adjustments made if necessary, by comparing their readings with those obtained using the Winkler method. The oxygen concentration was decreased by increasing the flow of nitrogen gas, which was regulated by a magnetic valve controlled by the oxygen meter. The flow of nitrogen gas was automatically switched off once the desired oxygen concentration was reached. To obtain very low oxygen concentrations, the water surface was covered with Plexiglas or floating plastic. This resulted in a stable and homogeneous oxygen concentration. Air was continuously bubbled through the control tank.

Each replicate consisted of a round plastic beaker (380 $\mathrm{ml}$ volume) with a lid. Holes in the sides of the beakers, covered with fine netting ( $0.5 \mathrm{~mm}$ mesh size), allowed all replicates to receive the same oxygen concentration while keeping the amphipods apart. Each beaker contained sieved, $3 \mathrm{~cm}$ deep sediment. At the end of the experiments, the amphipods were transferred to well-oxygenated water and the number of survivors counted after $30 \mathrm{~min}$.

Effect of artificial sea water. For Monoporeia affinis and Pontoporeia femorata, survival rates in natural and artificial sea water were determined at salinities of $6.5 \%$ and $9 \%$ for $34 \mathrm{~d}$. The same tests were also carried out on $M$. affinis with an exposure time at salinity $6.5 \%$ of $62 \mathrm{~d}$. The natural sea water was concentrated by evaporation to $9 \%$, and the artificial sea water was made up with special aquarium salt ('hw-Marinemix + Bio-elements', Wiegant GmbH, Germany). Intact plastic beakers $(380 \mathrm{ml})$ were used, filled with $3 \mathrm{~cm}$ of sieved sediment. Five ( $34 \mathrm{~d}$ experiments) and 10 replicates of each treatment (62 d experiments), with 6 amphipods $\left(\sim 1800 \mathrm{~m}^{-2}\right)$ in each, were included.

Tolerance to oxygen deficiency. In the first experiment, the oxygen concentration was gradually decreased in consecutive steps in order to determine approximately how sensitive the amphipods were. The experimental tanks $(215 \times 42 \times 15 \mathrm{~cm})$ were filled with natural sea water. The oxygen concentration was rapidly decreased (within $6 \mathrm{~h}$ ) to the target level. Exposure to each oxygen concentration lasted for $24 \mathrm{~h}$, starting with $0.8 \mathrm{mg} \mathrm{O} \mathrm{O}_{2} \mathrm{l}^{-1}(6.5 \%$ oxygen saturation) followed by $0.7(5.7 \%), 0.6(4.9 \%), 0.4(3.3 \%)$ and $0.3 \mathrm{mg} \mathrm{O}_{2} 1^{-1}(2.4 \%)$. For each species, 25 beakers with 4 amphipods each $\left(\sim 1200 \mathrm{~m}^{-2}\right)$, which is within their normal range of densities according to Ankar \& Elmgren (1976), were placed in the experimental tank. Five beakers per species were taken out each day and the survival rates recorded. Five control beakers with 4 amphipods each were examined at the end of the experiment for each species.

A second experiment was run in the same way, except that Monoporeia affinis alone was tested at a 
constant oxygen concentration of $0.3 \mathrm{mg} \mathrm{O}_{2} \mathrm{l}^{-1}(2.4 \%)$ in natural sea water for $3 \mathrm{~d}$.

In a third experiment, survival after $24 \mathrm{~d}$ at low oxygen concentrations was measured for Monoporeia affinis and Pontoporeia femorata. The oxygen concentrations studied (mean \pm SD) were $1.2 \pm 0.3(10 \%), 2.0 \pm$ $0.1(17 \%), 4.0 \pm 0.1(33 \%), 6.0 \pm 0.1(49 \%)$ and $11.7 \pm$ $0.2 \mathrm{mg} \mathrm{O} \mathrm{O}_{2} \mathrm{l}^{-1}$ (95\%, continuously air bubbled). Ten beakers for each treatment, with 4 amphipods in each $\left(\sim 1200 \mathrm{~m}^{-2}\right)$, were included. The experiment was conducted as described above, in tanks $(250 \times 40 \times 20 \mathrm{~cm})$ with artificial sea water.

Effect of salinity on tolerance to oxygen deficiency. Tolerance to a low oxygen concentration $10.2 \mathrm{mg} \mathrm{O}_{2}$ $1^{-1}=1.6 \%$ ) at slightly increased and decreased salinities was tested. Artificial sea water was used in tanks with dimensions of $54 \times 34 \times 32 \mathrm{~cm}$. The amphipods were acclimatised for $2 \mathrm{wk}$, without sediment, to salinities of $4 \%, 6.5 \%$ and $9 \%$. For each species and salinity, 18 beakers with 4 amphipods $\left(\sim 1200 \mathrm{~m}^{-2}\right)$ in each were included in each experimental treatment. The amphipods were exposed to the low oxygen concentration in the salinity of acclimation. The air-bubbled control consisted of 6 beakers for each species, and salinity and survival rate were determined at the end of the experiment.

In a second test of tolerance to oxygen deficiency at different salinities, the oxygen concentration was slightly higher, $0.6 \mathrm{mg} \mathrm{O} \mathrm{I}^{-1}(5 \%)$, and the salinities tested were $5 \%, 6.5 \%$ and $9 \%$. The artificial sea water and tanks used were the same as those described above. The amphipods were acclimatised for $2 \mathrm{wk}$ to the test salinities, without sediment. After the acclimation period, 20 beakers (for each species and salinity), with 6 amphipods $\left(\sim 1800 \mathrm{~m}^{-2}\right)$ each, were transferred to the test tanks. The control consisted of 6 beakers for each species and salinity and had a constant supply of air. The control survival rate was determined only once, at the end of the experiment.

Statistical methods. Results were statistically evaluated using analysis of variance (ANOVA). The multiple comparison test Student-Newman-Keuls (SNK) was used in cases where significant variation was found using the ANOVA, and the homogeneity of variance was tested with Cochran's C-test (Winer et al. 1991).

\section{RESULTS}

\section{Test of artificial sea water}

Survival rates over $34 \mathrm{~d}$ for the 2 species of amphipods did not differ significantly between water types (artificial vs natural) or salinities (6.5\% vs $9 \%$ ). There was, however, a difference in survival between species, with Monoporeia affinis having a higher survival rate ( 88 to $100 \%$ ) than Pontoporeia femorata (64 to $96 \%$ ), (ANOVA, $F=13.2$, p < 0.001). The $62 \mathrm{~d}$ survival rates for $M$. affinis likewise did not differ significantly between natural ( $92 \%)$ and artificial $(90 \%)$ sea water.

\section{Tolerance to oxygen deficiency}

Pontoporeia femorata was significantly more sensitive to a stepwise reduction in oxygen concentration (from 0.8 to $0.3 \mathrm{mg} \mathrm{O}_{2} \mathrm{l}^{-1}$ ) than Monoporeia affinis (2-factorial ANOVA, $F=33.3, p<0.001$ ). There was no significant difference in survival between days, and no interaction between day and oxygen concentration was found (Fig. 1). More than $70 \%$ of the initial number of $P$. femorata were dead after $5 \mathrm{~d}$, by which time the oxygen concentration had been reduced to $0.3 \mathrm{mg}$ $\mathrm{O}_{2} 1^{-1}$, whereas all $M$. affinis were still alive. All amphipods in the control groups ( $11.5 \mathrm{mg} \mathrm{O}_{2} \mathrm{l}^{-1}=94 \%$ ) were still alive at the end of the experiment. Comparison between the experimental and control groups on Day 5 revealed a significant interaction between oxygen concentration and species (ANOVA, $F=3.8, p<$ 0.01): P. femorata in the low-oxygen treatment had a significantly lower survival rate compared with $M$. affinis in the low-oxygen treatment and both $M$. affinis and $P$. femorata in the control (SNK).

After $1,2,3$, and $4 \mathrm{~d}$ of exposure to a constant concentration of $0.3 \mathrm{mg} \mathrm{O}_{2} \mathrm{l}^{-1}$ (2.4\% oxygen saturation) mortality rates for Monoporeia affinis were 4, 20, 56

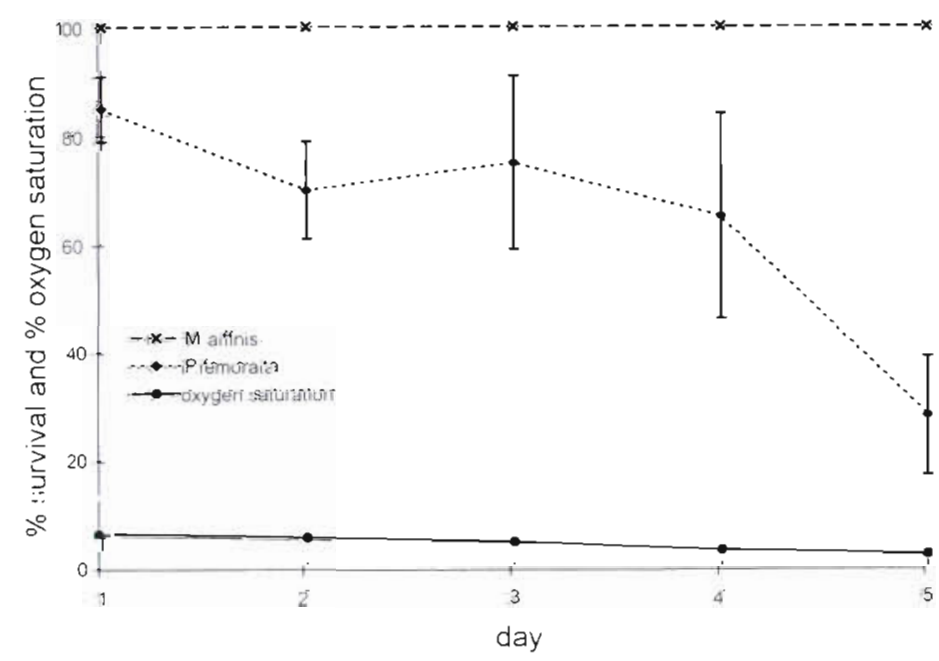

Fig. 1 Pontoporela femorata and Monoporeia affinis. Survival rate [mean \pm SEM (standard error of mean)] after a stepwise decrease during $5 \mathrm{~d}$ from 0.8 to $0.3 \mathrm{mg} \mathrm{O} \mathrm{I}^{-1}$ 


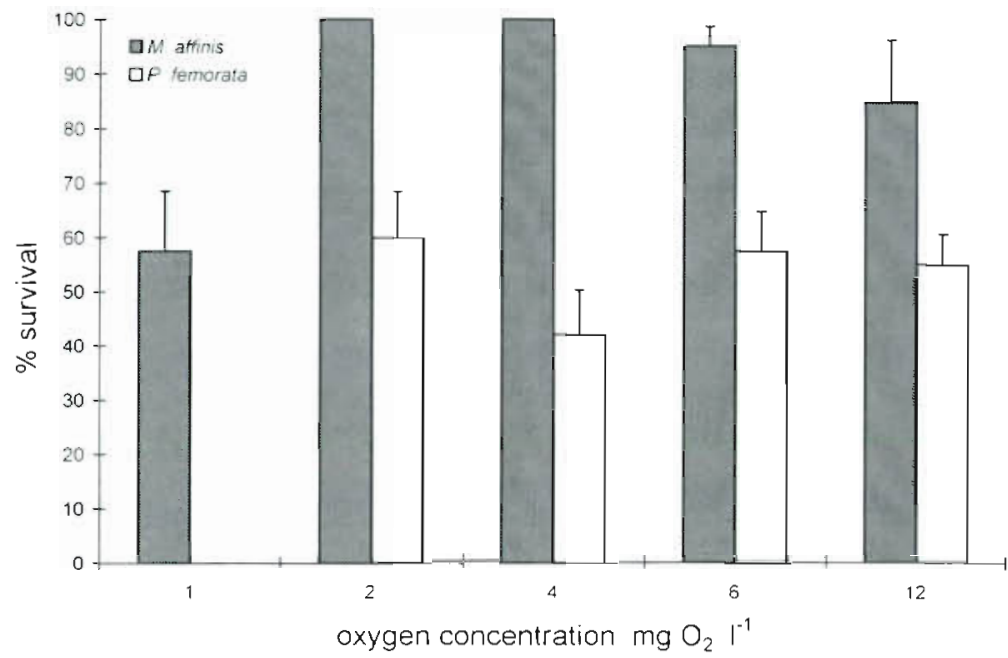

Fig. 2. Pontoporeia femorata and Monoporeia affinis. Survival rate (mean \pm SEM) after $24 \mathrm{~d}$ of exposure to $1.2,2.0,4.0,6.0$ and $11.7 \mathrm{mg} \mathrm{O}_{2} \mathrm{l}^{-1}$ oxygen treatment and $10.6 \mathrm{mg} \mathrm{O}_{2} \mathrm{I}^{-1}$ ( $86 \%$ oxygen saturation) in the control. More than $50 \%$ of both species had died after $24 \mathrm{~h}$ of exposure to nearly anoxic water at $0.2 \mathrm{mg} \mathrm{O}_{2} \mathrm{l}^{-1}$ (Fig. 3). No significant differences were detected between species or salinities. When the control and oxygen-deprived groups were compared at salinities of $9 \%$ and $6.5 \%$, a 3 -way interaction was found between oxygen concentration, species and salinity $(F=10.2$, $\mathrm{p}<0.01$ ). All oxygen-deprived groups had a significantly lower survival rate than all control groups, and survival among the control groups was (for reasons unknown) lower for P. femorata at 9\% (SNK).

In the next experiment, salinities of $5 \%$, $6.5 \%$ and $9 \%$ and an oxygen concentration of $0.6 \mathrm{mg} \mathrm{O} \mathrm{O}^{-1}(5 \%$ oxygen saturation) were used. The survival rate and $70 \%$ respectively. By contrast, all control $(11.3 \mathrm{mg}$ $\mathrm{O}_{2} \mathrm{I}^{-1}=92 \%$ oxygen saturation) $M$. affinis were still alive at the end of the experiment, and their survival rates were significantly higher compared with the group exposed to the low oxygen concentration at both Day 3 and 4 (ANOVA, $F=10.8, p<0.001$, SNK).

\section{Tolerance to long-term oxygen deficiency}

For both species, survival rates at $1.2 \mathrm{mg} \mathrm{O} \mathrm{O}_{2} \mathrm{l}^{-1}(10 \%$ oxygen saturation) were significantly lower compared with those at the other concentrations after $24 \mathrm{~d}$ (ANOVA, $F=22, p<0.001$, SNK, Fig. 2). Monoporeia affinis was more tolerant than Pontoporeia femorata (ANOVA, $F=127, p<0.001$ ). Lowest survival rate was found for $P$. femorata at $1.2 \mathrm{mg} \mathrm{O}_{2} \mathrm{l}^{-1}$, intermediate for $M$. affinis at $1.2 \mathrm{mg} \mathrm{O}_{2} \mathrm{l}^{-1}$ and P. femorata at 2, 4,6 and $11.7 \mathrm{mg} \mathrm{O}_{2} \mathrm{I}^{-1}$ and highest survival for $M$. affinis at $2,4,6$, and $11.7 \mathrm{mg} \mathrm{O}_{2} \mathrm{I}^{-1}(\mathrm{SNK})$.

\section{Effects of oxygen deficiency at different salinities}

In the first experiment, Monoporela affinis and Pontoporeia femorata were tested at salinities of $4 \%, 6.5 \%$ and $9 \%$. At a salinity of $4 \%$, no results were obtained for $P$. femorata since it did not survive acclimation. The mean oxygen concentration was $0.2 \mathrm{mg} \mathrm{O}_{2}$ $1^{-1} 1.6 \%$ oxygen saturation) in the low- after acclimation was nearly the same for all salinities and both species ( 64 to $69 \%$ for Monoporeia affinis, 56 to $69 \%$ for Pontoporeia femorata). The mean $( \pm \mathrm{SD}$ ) oxygen concentration in the experimental groups differed only marginally between treatments and was not significantly different; $5 \%=0.64 \mathrm{mg} \mathrm{O}_{2} \mathrm{l}^{-1}( \pm 0.04)$, $6.5 \%=0.57 \mathrm{mg} \mathrm{O}_{2} \mathrm{l}^{-1}( \pm 0.10), 9 \%=0.58 \mathrm{mg} \mathrm{O}_{2} \mathrm{I}^{-1}$ $( \pm 0.01)$. The statistical analysis (3-factorial ANOVA) showed that $P$. femorata was significantly more sensitive to oxygen deficiency than $M$. affinis $(\mathrm{p}<0.001)$. There was also a significant interaction between salinity and day ( $p<0.05$, Table 1, Fig. 4). M. affinis survived better than $P$. femorata at all 3 oxygen levels and M. affinis exposed to a salinity of $9 \%$ survived better than $M$. affinis at $6.5 \%$ and $5 \%$ in oxygen-deprived

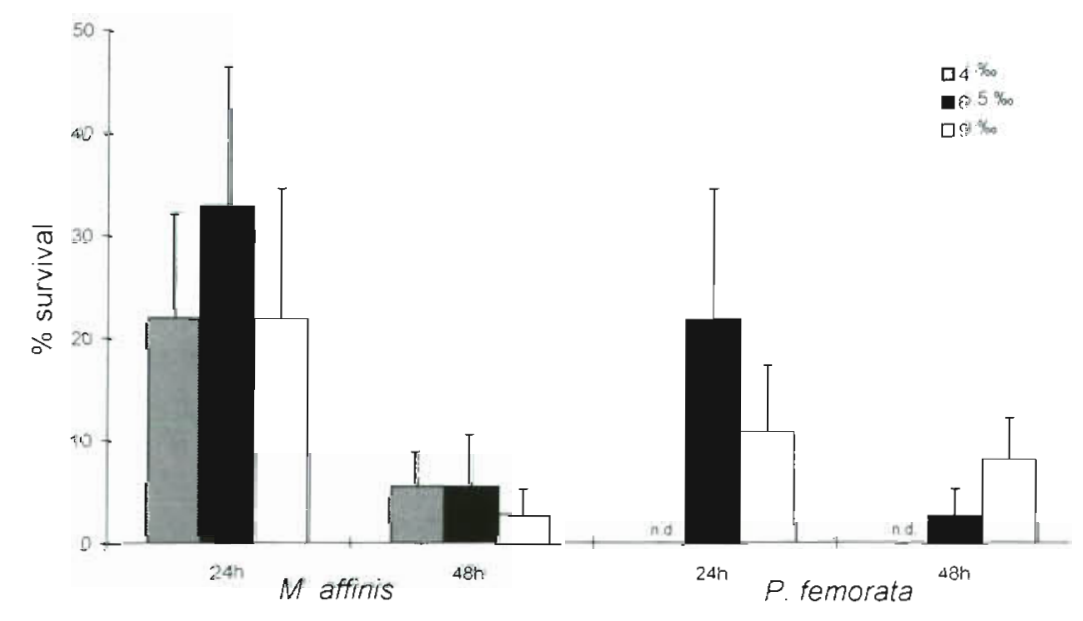

Fig. 3. Monoporeia affinis and Pontoporeia femorata. Survival rate (mean \pm SEM1) after 24 and 48 h at salinities of $4 \%, 6.5 \%$ and $9 \%$ and oxygen concentrations of $0.2 \mathrm{mg} \mathrm{O}_{2} \mathrm{l}^{-1}$ Control at $10.6 \mathrm{mg} \mathrm{O} \mathrm{I}^{-1}$ not shown. n.d.: no data obtanned 


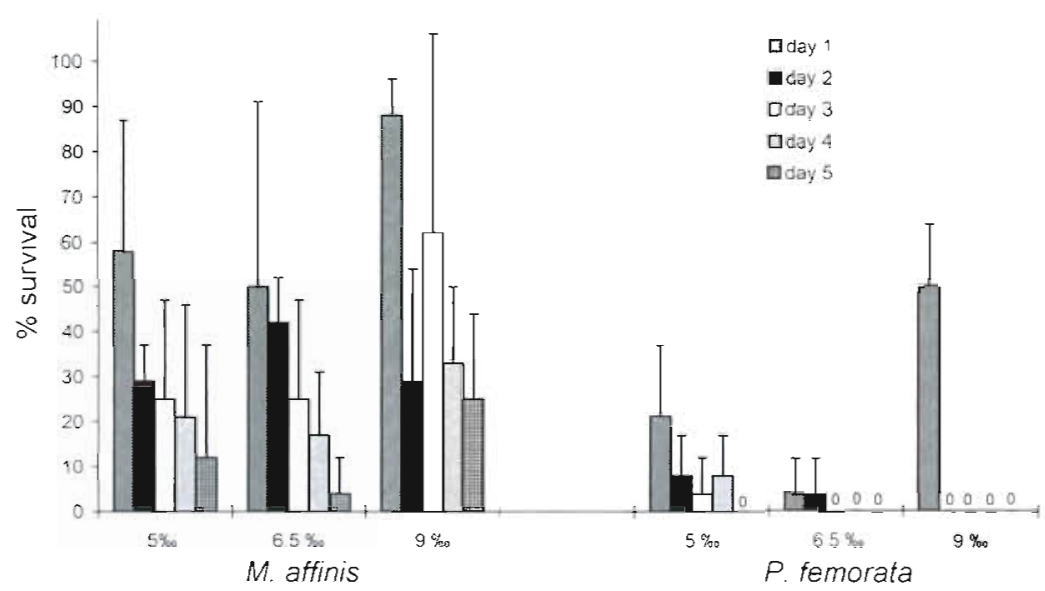

Fig. 4. Monoporeja affinıs and Pontoporeia femorata. Survival rates on Days 1 to 5 at salinities of $5 \%, 6.5 \%$ and $9 \%$ and an oxygen concentration of $0.6 \mathrm{mg} \mathrm{O}$ $\mathrm{I}^{-1}$ Controls at $11.2 \mathrm{mg} \mathrm{O}_{2} \mathrm{l}^{-1}$ not shown. $0=$ no survival

Table 1. Effects of the factors Species, Salinity and Day, and their interactions on the survival of Pontoporeia femorata and Monoporeia affinis at $0.6 \mathrm{mg} \mathrm{O} \mathrm{O}^{-1}$. ns: not significant

\begin{tabular}{|lcc|}
\hline Effect & F-value & p-value \\
\hline Species & 66.7 & $<0.001$ \\
Salinity & 6.5 & $<0.01$ \\
Day & 14.6 & $<0.001$ \\
Species $\times$ Salinity & 1.9 & ns \\
Species $\times$ Day & 1.9 & ns \\
Salinity $\times$ Day & 2.2 & $<0.05$ \\
Species $\times$ Salinity $\times$ Day & 0.6 & ns \\
\hline
\end{tabular}

treatments. Furthermore, the survival rate on Day 1 was higher at a salinity of $9 \%$ compared with survival rates for each of the other 4 days and salinities. Survival rates in the high-oxygen treatment (56 to 69\% survival, $11.2 \mathrm{mg} \mathrm{O}_{2} \mathrm{l}^{-1}=91 \%$ oxygen saturation) did not differ significantly between species or salinities. Furthermore, on Day 5, the control amphipods showed significantly higher survival than the amphipods exposed to the low-oxygen treatment (ANOVA, $F=$ 125, $p<0.001$ )

\section{DISCUSSION}

In this study, Monoporeia affinis and Pontoporeia femorata tolerated low oxygen values in the same range as those tolerated by other amphipods (Sprague 1963, Gamble 1970, Bulnheim 1979, Ritz 1980, Agnew \& Taylor 1985, Agnew \& Jones 1986, Nebeker et at 1992, Winn \& Knott 1992, Maltby 1995). Mortality was below $50 \%$ for both $M$. affinis and $P$. femorata after $24 \mathrm{~h}$ exposure to nearly anoxic water $\left(0.2 \mathrm{mg} \mathrm{O}_{2} \mathrm{l}^{-1}\right)$. In 3 ex- periments $M$ affinis tolerated oxygen deficiency better than $P$. femorata did.

Since more active animals have a higher metabolic rate and greater energy requirements, they are normally more sensitive to decreases in oxygen concentration (review in Davis 1975). For example, a comparison of the 2 brittlestars Amphiura filiformis and Amphiura chiajei showed that $A$. chia$j e i$, the species with the lower oxygen uptake, was more tolerant to oxygen deficiency (Rosenberg et al. 1991). Pontoporeia femorata has a lower respiration rate and is less active than Monoporeia affinis (Cederwall 1979) and was therefore expected to be the more tolerant of the 2 species of amphipods. Another fact suggesting that $P$. femorata should be more tolerant of oxygen deficiency is that, compared to $M$. affinis, it is found deeper in the sediment, where oxygen concentrations tend to be lower (Hill \& Elmgren 1987). However, it turned out that $M$. affinis was the more tolerant of the 2 species. $M$. affinis is a brackish-water species whereas $P$. femorata is a marine species (Segerstråle 1950, 1959), and brackish-water amphipods have been reported to be more tolerant to oxygen deficiency than marine amphipods (Bulnheim 1979, Ritz 1980). The salinity in the Askö area, where the amphipods were collected, is about $6.5 \%$, close to the lower limit of survival for $P$. femorata. It was therefore of interest to determine whether salinity-related stress could explain the lower tolerance to oxygen deficiency of $P$. femorata, compared with $M$. affinis. However, for as long as the amphipods survived the experimental salinity, there were only minor effects of salinity on their tolerance to oxygen deficiency. Other authors have reported the tolerance of marine invertebrates to oxygen deficiency to be affected at decreased salinity, with lower survival rates and earlier onset of impaired physiological responses (Theede et al. 1969, Stickle et al. 1989, Kristoffersson \& Kuosa 1990). Theede et al. (1969) suggested that euryhaline species are not affected by lowered salinity as long as the critical salinity limit is not reached. No significant effect of low salinity was detected in this study, even when $P$. femorata was tested close to its lower tolerance limit of $5 \%$.

Generally, Pontoporeia femorata showed a lower survival rate than Monoporeia affinis in long-term experiments (natural vs artificial water and tolerance), even at higher oxygen concentrations, which is in agreement with previous laboratory observations (Johansson unpubl.). However, in short-term experiments, no difference in survival of control $P$. femorata 
and $M$. affinis was found, except for P. femorata at $9 \%$, in the first salinity experiment.

In addition to Monoporeia affinis and Pontoporeia femorata, the below-thermocline macrobenthic community in the study area (near the Askö laboratory) includes the bivalve Macoma balthica, the isopod Saduria entomon, the priapulid Halicryptus spinulosus and the polychaete Harmothoe sarsi. Of these species, H. spinulosus is the most tolerant to oxygen deficiency, being able to withstand anoxia for as long as $60 \mathrm{~d}$ (Oeschger 1990). M. balthica is also very tolerant to anoxia, as indicated by a $50 \%$ mortality rate after $52 \mathrm{~d}$ (Dries \& Theede 1974), whereas S entomon can only withstand anoxia for about 10 d (Hagerman \& Szaniawska 1988, Kristoffersson \& Kuosa 1990). Few data are available on the tolerance of $H$. sarsi to low oxygen levels. In a pilot study, small individuals $(0.5$ to $1 \mathrm{~cm})$ survived oxygen concentrations below $0.2 \mathrm{mg} \mathrm{O}_{2} \mathrm{l}^{-1}$ for $2 \mathrm{~d}$, but all were dead after $4 \mathrm{~d}$ (Johansson unpubl, data). H. sarsi is, however, an early recolonizer in areas affected by low oxygen concentrations and, based on field data, considered to tolerate such conditions fairly well (Andersin et al. 1978). Thus the result here for the 2 amphipod species indicated that they are the least tolerant to oxygen deficiency of the macrobenthic species in the region of interest.

In the Gulf of Finland, no amphipods were found after an extended period with low oxygen concentrations, whereas after an increase in oxygen concentration, they recolonized the area (Andersin \& Sandler 1991). Gaston (1985) reported similar results, with amphipod numbers markedly reduced at oxygen concentrations below $2 \mathrm{mg} \mathrm{O}_{2} \mathrm{l}^{-1}$. Such reductions may have further ecological consequences since amphipods in the sediment are probably responsible for much of the bioturbation of the sediment. The deposit-feeding amphipod Pontoporeia hoyi was capable of creating a homogenised upper sediment layer (Robbins 1982). This means that processes taking place at or near the sediment-water interface will be disturbed if the amphipods die or become immobilised. In a review by Krantzberg (1985), bioturbation affected the nitrogen dynamics in the sediment by increasing nitrification and denitrification rates. Thus the inhibition of denitrification could reinforce the effects of nutrient enrichment by allowing increased rates of $\mathrm{NH}_{4}{ }^{+}$recycling, as suggested by Kemp et al (1990).

Due to their normally high abundance and importance as prey for fish and invertebrates, as well as their important contribution to biogeochemical cycling through their bioturbating activity, the 2 studied deposit-feeding species of amphipods are central components of the Baltic benthic assemblage (Elmgren et al. 1990). The present study shows them to be particularly sensitive to oxygen deficiency, with Pontoporeia femorata being most susceptible.
Acknowledgements. I thank Lars Byrén, Britt Stämfors and Barbro Söderlund for field and laboratory assistance, and Ragnar Elmgren for comments on the manuscript. The Stockholm Centre for Marine Research provided access to boat and field station facilities. This study was supported by the Swedish Natural Science Research Councll and the Swedish Environmental Protection Agenr:

\section{LITERATURE CITED}

Abrams P. Hul C. Elmgren R (1990) The functional response of the predatory polychaete, Harmothoe sarsi, to the amphipod, Pontoporeia affinis. Oikos 59:261-269

Agnew DJ, Jones MB (1986) Metabolic adaptations of Gammarus duebeni Liljeborg (Crustacea, Amphipoda) to hypoxia in a sewage treatment plant. Comp Biochem Physiol A 84:475-478

Agnew DJ, Taylor AC (1985) The effect of oxygen tension on the physiology and distribution of Echinogammarus pirloti (Sexton \& Spooner) and E. obtusatus (Dahl) (Crustacea: Amphopoda). J Exp Mar Biol Ecol 87:169-190

Andersin AB, Cederwall H, Gosselck $F$, Jensen JN, Josefsson A, Lagzdins G, Rumohr H, Warzocha J (1990) Second periodic assessment of the state of the marine environment of the Baltic Sea, 1984-1988; Background document. Baltıc Sea Environ Proc 35B:211-275

Andersin AB, Lassing J, Parkkonen L, Sandler H (1978) The decline of macrofauna in the deeper parts of the Baltic proper and the Gulf of Finland. Kieler Meeresforsch, Sonderh 4:23-52

Andersin AB, Sandler H (1991) Macrobenthic fauna and oxygen deficiency in the Gulf of Finland. Memo Soc Fauna Flora Fenn 67:3-10

Aneer G (1975) Composition of the food of the Baltic herring (Clupea harengus L.), fourhorn sculpin (Myoxocephalus quadricornis L.) and eel-pout (Zoarces viviparus L.) from deep soft bottom trawling in the Askö-Landsort area during two consecutive years (1970-1972). Merentutkimuslait Julk 239:146-154

Ankar S, Elmgren R (1976) The benthic macro- and meiofauna of the Askö-Landsort area (Northern Baltic Proper). A stratified random sampling survey. Contrib Asko Lab Univ Stockholm 11:1-115

Baden SP, Loo LO, Pihi L, Rosenberg R (1990) Effects of eutrophication on benthic communities including fish: Swedish west coast. Amblo 19:113-122

Bulnheim HP (1979) Comparative studies on the physiological ecology of five euryhaline Gammarus species. Oecologia 44:80-86

Cederwall H (1979) Diurnal oxygen consumption and activity of two Pontoporeia (Amphipoda, Crustacean) species. In: Naylor E, Flartnoll RG (eds) Cyclic phenomena in marine plats and anmals. Pergamon Press, Oxford, p 309-316

Cederwall H, Elmgren R (1980) Biomass increase of benthic macrofauna demonstrates eutrophication of the Baltic Sea. Ophelia Suppl 1:287-304

Cederwall H, Elmgren R (1990) Biological effects of eutrophication in the Baltic Sea, particularly the coastal zone Ambio 19:109-112

Davis JC (1975) Minimal dissolved oxygen requirements of aquatic life with emphasis on Canadian species a review. $J$ Fish Res Bd Can 32:2295-2332

de Jong VN, Boynton W, D'Elia CF, Elmgren R, Welsh BL (1994) Responses to developments in eutrophication. in four different North Atlantıc estuarine systems. In: Dyer KR, Orth RJ (eds) Changes in fluxes in estuaries. International 
symposium series. Olsen \& Olsen, Fredensborg, p 179-196

Diaz RL, Rosenberg $R$ (1995) Marine benthic hypoxia: a review of its ecological effects and the behavioural responses of benthic macrofauna. Oceanogr Mar Biol Annu Rev 33:245-303

Dries RR, Theede H (1974) Sauerstoffmangelresistenz mariner bodenevertebraten aus der westlichen Ostsee. Mar Biol 25:327-333

Elmgren R (1989) Man's impact on the ecosystem of the Baltic Sea: energy flows today and at the turn of the century. Ambio 18:326-332

Elmgren R, Ankar S, Ejdung G (1990) Amphipods of the genus Pontoporeia as key elements in the Baltic benthos. Annls Zool Fenn 27:303-304

Frilıgos $N$, Zenetos A (1988) Efesis bay anoxia: conditions and benthıc community structure. PSZN J: Mar Ecol 9:272-290

Gamble JC (1970) Anaerobic survival of the crustaceans Corophium volutator, C. arenarium and Tanais chevreuxi. J Mar Biol Assoc UK 50:657-671

Gaston RG (1985) Effects of hypoxia on macrobenthos of the inner shelf off Cameron, Louisiana. Estuar Coast Shelf Sci $20.603-613$

Gosselck F, Georgi F (1984) Benthic recolonization of the Lübeck Bight (Western Baltic) in 1980/81. Limnologica 15: 407-414

Hagerman L, Szaniawska A (1988) Respiration, ventilation and circulation under hypoxia in the glacial relict Saduria (Mesidotea) entomon. Mar Ecol Prog Ser 47:55-63

Hill C, Elmgren R (1987) Vertical distribution in the sediment in the co-occurring benthic amphipods Pontoporeia affinis and $P$. femorata. Oikos 49:221-229

Hill C, Elmgren R (1992) Predation by the isopod Saduna entomon on the amphipods Monoporeia affinis and Pontoporeia femorata: experiments on prey vulnerability. Oecologia 91:153-156

Järvekülg A (1973) Distribution and ecology of local populations of benthic glacial relicts. Oikos Suppl 15:91-97

Jørgensen BB (1980) Seasonal oxygen depletion in the bottom waters of a Danish fjord and its effect on the benthic community. Oikos 34:68-76

Kemp WM, Sampou PA, Caffrey J, Mayer M, Henriksen K, Boynton WR (1990) Ammonium recycling versus denitrification in Chesapeake Bay sediments. Limnol Oceanogr 35:1545-1563

Krantzberg G (1985) The influence of bioturbation on physical, chemical and biological parameters in aquatic environments: a review. Environ Pollut Ser A Ecol Biol 39: 99-122

Kristoffersson R, Kuosa PL (1990) Studies on the ecological physiology of Saduria entomon. Annls Zool Fenn 27:267

Larsson U. Elmgren R, Wulff $F$ (1985) Eutrophication and the Baltic Sea: causes and consequences. Ambio 14:9-14

Leppäkoski E (1969) Transitory return of the benthic fauna of the Bornholm Basin, after extermination by oxygen insufficlency. Cah Mar Biol X:163-172

Llansó JR (1992) Effects of hypoxia on estuarine benthos: the lower Rappahannock River (Chesapeake Bay), a case study. Estuar Coast Shelf Sci 35:491-515

Lopez G, Elmgren R (1989) Feeding depths and organic absorption for deposit-feeding benthic amphipods Pontoporela affinis and Pontoporeia femorata. Limnol Oceanogr 34:982-991

Maltby $L$ (1995) Sensitivity of the crustaceans Gammarus pulex (L.) and Asellus aquaticus (L.) to short-term exposure to hypoxia and unionized ammonia: observations and possible mechanisms. Water Res 29:781-787
Matthäus W, Franck H (1992) Characteristics of major Baltic inflows - a statistical analysis. Cont Shelf Res 12 $1375-1400$

Nebeker AV, Onjukka ST, Stevens DG, Chapman GA, Dominguez SE (1992) Effects of low dissolved oxygen on survival, growth and reproduction of Daphnia, Hyalella and Gammarus. Environ Toxicol Chem 11:373-379

Nilsson HC, Sköld M (1996) Arm regeneration and spawning in the brittle star Amphiura filiformis (O.F. Müller) durng hypoxia. J Exp Mar Ecol Biol 199:193-206

Oeschger R (1990) Long-term anaerobiosis in sublittoral marine invertebrates from the Western Baltic Sea: Halicryptus spinulosus (Priapulida), Astarte borealis and Arctica islandica (Bivalvia). Mar Ecol Prog Ser 59:133-143

Officer CB, Biggs RB, Taft JL, Cronin LE, Tyler MA, Boynton WR (1984) Chesapeake Bay anoxia: origin, development, and significance. Science 223:22-27

Ritz DA (1980) Tolerance of intertidal amphipods to fluctuating conditions of salinity, oxygen and copper. J Mar Biol Assoc UK 60:489-498

Robbins JA (1982) Stratigraphic and dynamic effects of sediment reworking by Great Lakes zoobenthos. Hydrobiologia $92: 611-622$

Rosenberg R, Elmgren R, Fleischer S, Jonsson P, Persson G, Dahlin $H$ (1990) Marine eutrophication case studies in Sweden. Ambio 3:102-108

Rosenberg R, Hellman B, Johansson B (1991) Hypoxic tolerance of marine benthic fauna. Mar Ecol Prog Ser 79: $127-131$

Segerstråle SG (1950) The amphipods on the coasts of Finland-some facts and problems. Soc Sci Fenn Commentat Biol X 14:2-28

Segerstråle SG (1959) Synopsis of data on the crustaceans Gammarus locusta, Gammarus oceanicus, Pontoporeia affinis, and Corophium volutator (Amphipoda Gammaridea). Societas Scient Fenn Commentat Biol XX 5 $7-23$

Sprague JB (1963) Resistance of four freshwater crustaceans to lethal high temperature and low oxygen. J Fish Res Bd Can 20:387-415

Steimle FW, Sindermann CJ (1978) Review of oxygen depletion and associated mass mortalities of shellfish in the Middle Atlantic Bight in 1976. Mar Fish Rev 40:17-26

Stickle WB, Kapper MA, Liu LL, Gnaiger E, Wang SY (1989) Metabolic adaptations of several species of crustaceans and molluscs to hypoxia: tolerance and microcalorimetric studies. Biol Bull 177:303-312

Theede H, Ponat A, Hiroki K, Schlieper C (1969) Studies on the resistance of marine bottom invertebrates to oxygendeficiency and hydrogen sulphide. Int $J$ Life Oceans Coast Waters 2:325-337

Turner RE, Rabalais NN (1994) Coastal eutrophication near the Missisippi river delta. Nature 368:619-621

Weber JM, Kramer DL (1983) Effects of hypoxia and surface access on growth, mortality, and behaviour of juvenile guppies, Poecilia reticulata. Can J Fish Aquat Sci 40: $1583-1588$

Widdows J, Newell RIE, Mann R (1989) Effects of hypoxia and anoxia on survival, energy metabolism, and feeding of oyster larvae (Crassostrea virginica, Gmelin). Biol Bull 177:154-166

Winer BJ, Brown DR, Michels KM (1991) Statistical principles in experimental design. McGraw-Hill Inc, New York

Winn RN, Knott DM (1992) An evaluation of the survival of experimental populations exposed to hypoxia in the Savannah River estuary. Mar Ecol Prog Ser 88:161-179 